\title{
СПОСОБЫ СОЗДАНИЯ ИРОНИЧЕСКОГО СТИЛЯ ЯЗЫКА КРОССВОРДОВ
}

Кажан В. І., Калініна Р. П. Способи створення іронічного стилю мови кросвордів.

Статтю присвячено особливостям мовного оформлення сучасних кросвордів. Проаналізовано різноманітні прийоми мовної гри: полісемія, каламбур, парономазія, прецедентні феномени, каламбурні словотвірні засоби тощо.

Ключові слова: кросворд, гумористичний стиль, іронічний стиль, мовна гра, полісемія, каламбур, парономазія, фразеологізми, прецедентний феномен.

Кажан В. И., Калинина Р. П. Статья посвящена особенностям языкового оформления современных кроссвордов. Проанализированы разнообразные приемы языковой игры: полисемия, каламбур, парономазия, прецедентные феномены, каламбурные словообразовательные средства и др.

Ключевые слова: кроссворд, юмористический стиль, иронический стиль, языковая игра, полисемия, каламбур, парономазия, фразеологизмы, прецедентный феномен.

Kazhan V. I., Kalinina R. P. Methods of creating an ironic style in crosswords language.

The article deals with the peculiarities of the linguistic means of the modern crosswords. The different methods of the linguistic game are represented in this article. The () В. И. Кажан, Р. П. Калинина, $2013 . \quad$ - 267- 
most important among them are: polysemy, paronomasia, phraseological unit, precedent phenomena, word-forming means etc.

Key words: crossword, humorous style, ironic style, language game, polysemy, pun, paronomaziya, idioms, precedent phenomenon.

В конце XX в. в русскоязычной прессе появились еженедельные журналы «Арт-Мозаика», «Телескоп», «Теленеделя», на страницах которых печатаются кроссворды под рубриками «Эрудит», «Веселый», «Шевели извилинами», «Смеяться полезно», «И в шутку, и всерьез», «Давайте смеяться» и др.

Кроссворды носят развлекательно-познавательный и интеллектуальный характер, в них часто информационная направленность соседствует с юмором и игрой, «формой эстетически направленного языкового творчества, приближенной к возможностям каждого» [1, с. 227]. Под влиянием преобразований в обществе, происходящих на рубеже веков, возникают новые тенденции в языке СМИ, что отражается в его «свободе» [2, с. 55], отклонении от стандартных форм выражения.

Язык кроссвордов стремится к передаче экспрессивноиронического, а подчас и сатирического авторского отношения, поэтому в текстах - заданиях и ответах используются как традиционные, так и нетрадиционные языковые средства, нарушающие нормативные установки.

С целью создания шутки, иронии, насмешки авторы кроссвордов прибегают к таким распространенным игровым формам, как: палиндром, шарада, анаграмма, загадка. Приведем примеры: Одно из названий фразы-перевертьима - А муза рада музе без ума да разума (палиндром); Загадка ребусника Синицкого, начинающияся словами: «Мой первый слог на дне морском» (шарада); Вкусный и полезный плод, анаграмма к слову «спаниель» (апельсин); Словарная головоломка, что перед вами (кроссворд); Детская игра, абсолютныл чемпионом мира по которой является снежный человек (прятки); Гашеная, но не известь, с зубцами, но не пила, спрятана в спецчильный альбом, но не фотография (марка); Какой-то шутник сказал, что он - это “Иван Д» наоборот (диван); Я горячее храню, я холодное храню - я и печь, $и$ холодильник вам в походе заменю (термос).

Важную роль в подаче и решении вопроса-задания играет смысловая емкость каждого компонента. Авторы кроссвордов, отказываясь от обычных словарных определений слов, заменяя их шутливыми, юмористическими, словно создают новый толковый словарь для играющих. Например: Бронежсилет для настоящих 
богатырей (кольчуга); «Ночник» стратегического значения (маяк); По предположению насмешника, это конь, ушедший из кавалерии в авиацию (Пегас); Гербом счастья от кузнеча назвал ее юморист (подкова); Собрание сочинений многих авторов про одного героя (досье); Разбитый символ разбитых надежд, пришедший к верящим в приметь из пушкинской сказки (корыто); Как заметила одна дама, это ускоренные курсы по обмену опытом между больными (поликлиника); «Куча времени», не имеющая множественного числа (вечность); Чужая мысль, украшающая собственную точку зрения (цитата).

Одним из распространенных приемов оформления кроссвордов является включение в задания и ответы как стилистически нейтральной, так и маркированной лексики. В одном контексте могут объединяться и однородные, и разнородные стилевые элементы (напр., разговорнопросторечное слово - книжное слово (или термин), устаревшее слово термин (термины), общеупотребительное слово - устаревшее слово. С помощью подобных контрастных столкновений двух и более слов усиливается экспрессивно-эмоциональная оценка понятий, предметов, явлений. Сошлемся на примеры: Это ужастик в снах древних германцы приписывали проискам эльфов (кошмар); «Мокрое дело» по-крупному, выдаваемое, как правило, за правое (террор); Шумное место, которое «фильтруют», «разводят» и за которое требуют «ответить» (базар); «Округлившиеся» котлеты, «спутавииеся» с рисом (тефтели); «Сдвиг по фазе» применительно к костям сустава (вывих); "Расслабуха» на языке медиков и психологов (релаксация); Любитель поживиться за чужсои счет - одним жаргонным словечком (иаромыжник); Много «денег» из ничего, в итоге - никаких денег, одна бумага («кукла»); Подводный «спотыкач» из кораллов в море (риф).

В заданиях к кроссвордам активно используется многозначность задуманных слов, помогающая, подсказывающая правильный ответ. Например: Когда-то осадное орудие на земле, теперь спасительное средство в небе (катапульта); У Петра I - увеселительное мероприятие, у ООН - нудное собрание (ассамблея); Его подает клаксон и доброжелатель в компетентные органы (сигнал); Некоторые в ней до сих пор находят детей, а иные за детей ею расплачиваются (капуста); Воинское построение, ставшее и женской прической, и вырезом блузки (каре); Для пилота и городошника это фигура, для Гвидона - место заточения, для женщинны - отсутствие всякой фигуры (бочка).

$\mathrm{C}$ целью создания иронических номинаций и юмористических определений слов авторы кроссвордов используют перифразы, в () В. И. Кажан, Р. П. Калинина, $2013 . \quad$ - 269- 
которых с помощью описательных оборотов речи (чаще словосочетаний) указываются признаки неназванного прямо предмета: «Остекленевшая》 живопись (витраж); “Клизма» в таблетках (слабительное); Подружка геометрии (алгебра); Худиее, во что может превратиться отдельно взятый милицииоер, и название ему «... в погонах» (оборотень).

Большинство из зафиксированных перифраз являются индивидуально-авторскими: Шутник назвал ее «дождиком мелкого помола» (изморось); Это мороженое из дождя, по мнению маленькой девочки (снег); Юморист назвал ее «букетом из хвороста» (вязанка).

Многим из них свойственно оценочное переносное метафорическое значение одного или нескольких компонентов: Убежище испуганной дуии (пятки); Меченый деликатес (икра); Шутник считает их мыслями повышенной нелепости (бредни).

Индивидуально-авторские составные наименования не обладают структурно-смысловым единством и воспроизводимостью, они не стали привычными, поэтому заключаются в кавычки: Работник аэропорта, которого в шутку называют «небесным стрелочником» (диспетчер); «Кольгбельная в таблетках» (снотворное); «Братская могила» некогда жизненно важных бумаг (архив).

Усилению однозначности, ироничности и экспрессивности текстов-заданий, а также ответов способствуют парадигматические ряды синонимических номинаций, которые могут быть представлены 2-5 единицами. Приведем примеры: Удивление, доведенное до крайности (изумление); Уныние, тоска, или депрессия - словом из ХІХ столетия (меланхолия); Синонимь искомого слова - самолюбие, самомнение, спесь (амбициозность); Сложное запутанное дело: замешательство, беспорядок, сумятица (заваруика). Характерно чередование как нейтральных, так и разностилевых синонимов: книжных, устаревших, разговорных, жаргонных. Подобное объединение в синонимической паре или ряде разных стилистических сфер способствует созданию речевой экспрессии и иронии: Бред сивой кобыльл одним словом (ахинея); Враг и захватчик для наших далеких прашуров (супостат); Огнестрельный синоним босса (патрон); Девушка - «щуепа» в сердие доброго молодчуа (зазноба); И фингал, и синяк, и даже фонарь (в определенном месте) на языке медработника (гематома).

Иногда синонимический ряд усиливается и становится более выразительным благодаря градации. Например: 1. Обожатель, воздыхатель, кавалер, почитатель (поклонник); 2. Отсутствие порядка, или кавардак, тарарам (неразбериха). В подобных примерах 
наивысшей степенью усиления значения обладают синонимы-ответы (№1 - книжный синоним, №2 - разговорный).

Определенную роль играют и антонимы со значением противопоставления или сопоставления, т. е. «более слабого противопоставления» [3, с. 22]. Например: Кто-то из великих сказал, что это то, чего остерегается умный и на что рассчитывват глупец (случай); Когда-то особа, приближенная к императору, но не Киса Воробьянинов (вельможса); Если поверить, что наглость - второе счастье, то тогда это - второе несчастье (скромность); Шарж, но не нарисованный, а зарифмованный (эпиграмма); Оптимист для вписывания слов в кроссворд использует исключительно ручку, а пессимист - ... (карандаш).

С целью достижения комического эффекта авторы кроссвордов обращаются к каламбурам, игре слов, основанной на парономазии, намеренно сближают сходнозвучащие слова в тексте - задании и ответе. Например: Фривольнылй наряд для вольного борияа (трико); Двусмысленные намеки одним франиузским словом, очень похожсм на наш знак согласия (экивоки); Удар в боксе, который легко спутать с мясным блюдом «антрекот» (апперкот); Умудренный стареи с Востока, которого многие путают с саксаулом (аксакал); Воспаления, ставящие уии «на уии» (медищинский термин) (отит); Би-Би-Гуди - в автомобиле прежних времен (клаксон); Найдите каламбур во фразе: исполняемая актером в театре, кино, на телевидении роль бандь (бандероль); Горе-сантехник, не столько чинящуий, сколько ломаюший оборудование в душевых (убивец окаянный) - душегуб (Здесь к стилистически маркированному слову душегуб (убивец окаянный) автор подбирает семантический неологизм, тем самым сталкивая в одном слове два омонимических корня: душ и душа).

Хотя паронимическая аттракция предполагает множественность интерпретаций каждого случайного сближения слов, в рамках текста кроссворда, как мы убедились, предполагается только один ответ.

В формулировке заданий к кроссвордам важную роль играет использование фразеологических единиц, которое свидетельствует об определенной установке авторов на шутку, иронию, языковую игру.

Фразеологические единицы в кроссвордах используются своеобразно. В контекстах заданий они, как правило, трансформируются, отдельные их компоненты могут употребляться обособленно или выступать в качестве смысловых центров: Самая «лапчатая» из русских птичьих фамилий (Гусев; ср. фр.: «гусь лапчатый»); Обувь, промедшая огонь и воду, но однозначно не домедмая до медных труб (опорки; ср.

() В. И. Кажан, Р. П. Калинина, $2013 . \quad$ - $271-$ 
фр.: «пройти сквозь огонь, воду и медные трубы»); То, что можно перегнуть, даже не держа в руках (палка; ср.фр.: «перегнуть палку»); Медицинская процедура, которая почему-то не помогает мертвому (припарки; ср. фр. «поможет, как мертвому припарки»); «Секретом ...» называют то, что ни для кого секретом не является (Полишинель; ср. фр.: секрет полишинеля»); «Яйцуо, которое вопреки поговорке, может курицу поучить (вундеркинд; ср. фр.: «яйца курицу не учат»).

Наблюдаются случаи расширения компонентного состава фразеологических единиц. Сошлемся на примеры: Шутник отозвался о нем, как о человеке, который знает людей на ЗУБок (дантист; ср. фр.: «выучить на зубок»); Обмен шила на мыло с чувством взаимного удовлетворения (бартер; ср. фр.: «менять шило на мыло»). Значение фразеологизма может передаваться описательно, при этом ключевые слова содержатся в ответе к кроссворду. Например: Юморист как-то заметил, что оно - спутник вырвавщейся на свободу пуговицы (мясо; ср. фр.: «вырвать с мясом»); Возвращение долга в год по чайной ложке (дозировка; ср. фр.: «через час по чайной ложке»).

В результате структурно-семантических преобразований фразеологических единиц могут возникнуть авторские слова и выражения, созданные по языковым моделям. Например: Водяная крыса, с которой многие знакомы «шапочно» (ондатра; ср. фр.: «шапочное знакомство»). Конечно, вне текста задания смысл образованного неологизма утрачивает прозрачность.

В кроссворды вводятся не только прецедентные фразеологические структуры, но и цитаты юмористов, крылатые выражения известных людей, пословицы, поговорки, рекламные слоганы. Источником прецедентов становятся также популярные песни, кинофильмы, мультфильмы, художественные произведения. Подобные включения делают тексты - задания к кроссвордам более интеллектуальными, яркими, загадочными. «Прецедентные феномены» могут функционировать в кроссвордных контекстах без структурных и семантических изменений. Например: Древнегреческий философ Демокрит назвал его тенью дела (слово); Главным достоинством стиля считал это Аристотель (ясность); И «искусство возможного», как отмечал Бисмарк, и «искусство невозможного», как бы возразил ему Гавел (политика); В рубаи Авиценны есть такая фраза: «Вино наш друг, но в нем живет ... . Пьешь много - яд, немного пьешь лекарство» (коварство); Трапеза, которую Диоген советовал устраивать: богачу - когда хочет, бедняку - когда может (обед); Демосфен и демагог «в одном флаконе» (краснобай); Японский 
разведчик и ипион, лазутчик и киллер «в одном флаконе» (ниндзя); Гейне назвал его «аристократом среди животных» (человек).

Но все же чаще языковая игра базируется на частичной и даже полной морфологической и синтаксической трансформации прецедентных текстов. Например: Kопоть, которая, если верить поговорке, тем белее, чем хуже идут дела (сажа; ср. фр.: «дела как сажа бела»); Нечто птичье, что насылают на человеческий язык из расхожей поговорки (типун; ср. фр.: «типун тебе на язык»); Предмет, поисками которого японцы занимаются на дне речки, а русские - в стоге сена (иголка; ср. фр.: «как иголка в стогу сена»); Можно предположить, что эту печь назвали в честь любителей ананасов и рябчиков (буржуйка; ср.: Ешь ананасы, рябчиков жуй, день твой последний приходит, буржуй (В.Маяковский).

Встречается контаминация двух прецедентных построений с типичными преобразованиями: Согласно народной мудрости, куда ни кинь, всюду он, и вышибить его можно ему подобным (клин; ср. фр.: «куда ни кинь, всюду клин» и «клин клином вышибают»); Если она действительно в вине, то как она может глаголить устами младенца (истина; ср. фр.: «истина в вине», «устами младенца глаголет истина»); Они представляют упрямую вещьь, но при этом говорят «сами за себя» (факты ; ср. фр.: «факты - упрямая вещь»; «факты говорят сами за себя»).

Изредка прецедентная структура полностью деформируется: Ктото пошутил, что это единственная золотая «вещьь», не признаваемая женшинами (золото; ср. фр.: «слово - серебро, молчание - золото»); $B$ город Ньюкасл англичане не ездят со своим углем; а этот предмет мы не берем в Тулу (самовар; ср. фр.: «со своим самоваром в Тулу не ездят»).

«Оживляют» тексты - задания кроссвордов новые слова, созданные авторами в основном по продуктивным словообразовательным моделям. Например: «Думец» времен Бориса, но не Ельциина, а Годунова (боярин); Самый «галопистый» галоп ломади или собаки (карьер); По мнению юмориста, этот прибор из породы КОВРОсосущих (пьлесос); БАСКОВитый и ЛАНЦАвитый голосок (тенор); Кто-то пошутил, сказав, что это - выезд на лоно природы с иелью поПИКНИКовать (вылазка).

Широкое применение на словообразовательном уровне в кроссвордах находит языковая игра, основанная на целенаправленном выделении внутренней формы или ее частей. Заметим, что игра близких по морфемной структуре слов часто усиливается средствами графики и орфографии. Сошлемся на примеры: Насмешник утверждал, что он пользуется этой ЛЕСТЬницей для карьерь ๑ В. И. Кажан, Р. П. Калинина, $2013 . \quad$ - $273-$ 
(подхалим); Рыбацкая наГРУЗка к червяку (грузило); ОЧЕРЕДЬное огнестрельное оружие (автомат); Овощная мешанина, которую заКВАСили (окрошка); ОСЛЕПИТельный фонарь, изобретенный Кулибиным в 1779 году (прожектор); ЧОКнутое время Нового года (декабрь); «Клуб» весельхх и ДОХОДчивых брокеров (биржса); Кто-то пошутил, назвав ее летящим космическим ГОЛОВАстиком (комета).

Внутренняя форма, подчеркивая звуковую яркость слова, заставляя читателя задерживать внимание на важном компоненте, может или оставаться без изменений, или расширяться за счет вставки не присущего данной структуре элемента. Например: ЛЫКОрованные туфли от деревенских умельцев (лапти); Объект СТРАСТЬной охоть настойчивого поклонника (пассия); СУПтильная кухонная утварь (кастрюля); КОРРИДорная европейская страна (Испания); «НОГОняй», бъющий по ушам соседям снизу (топот).

Иногда для создания авторского семантического неологизма к обычному слову прибегают к ложной этимологизации, в результате чего возникают омонимы: общеязыковое слово - авторский неологизм: Лекарство, которое можно назвать ЖАРгоном не по значению этого слова, а по способу действия на организм (аспирин).

Изобретательность авторов кроссвордов нередко направлена на то, чтобы не только актуализировать внутреннюю форму слова, но и обнажить этимологический корень, тем самым подсказать правильный ответ: Хобби для проНЫР с аквалангом (дайвинг); Знаток назвал его продукцией КУРИЛьской гряды огородника (самосад); ГНУСная стая мелких насекомых (мошкара); НАДУВАТЕЛЬство - его прямая и единственная задача (насос).

Таким образом, яркость и неожиданность способов выражения мысли-задания, удачная языковая игра создают особый иронический стиль языка кроссвордов, привлекают внимание читателей и побуждают их к активному сотворчеству с автором.

\section{Литература}

1. Красильникова Е. В. «Почему не говорят?» / Е. В. Красильникова // Развитие современного русского языка. 1972. Словообразование. Членимость слова. - М. : Наука, 1975. - С. 221-227.

2. Крысин Л. П. Литературная норма и речевая практика газет / Л. П. Крысин // Язык современной публицистики : сб. статей / Сост. Г. Я. Солганик. - [2-е изд., испр.]. - М. : Флинта: Наука, 2007. - С. 44-57.

3. Новиков Л. А. Русская антонимия и ее лексико-графическое описание : вступительная статья / Л. А. Новиков // Львов М. Р. Словарь антонимов русского языка ; под ред. Л. А. Новикова. - М. : Русский язык, 1984. - С. 5-30.

Стаття надійшла до редакції 15.11.2013 p. 